\title{
AQUECIMENTO GLOBAL, LICENCIAMENTO E ANÁLISE DE IMPACTOS AMIBIENTAIS
}

\section{JOÃO ALFREDO TELLES MELO}

Mestre em Direito pela Universidade Federal do Ceará. Professor de Direito Ambiental na FA7. Consultor do Greenpeace. Advogado. joaoalfredo5050@yahoo.com.br

Ainda nos encontramos, em todo o mundo, sob os impactos da divulgação dos relatórios, divulgados neste ano, do Painel Intergovernamental sobre Mudanças Climáticas (IPCC), organismo criado pelo Organização das Nações Unidas (ONU) em 1988, para estudar os fenômenos atmosféricos que têm se abatido sobre o planeta nos últimos anos. Em 01.fev.2007, mais de 600 especialistas de 40 países publicaram o quarto relatório de avaliação sobre a base científica das mudanças climáticas (AR4) e afirmaram de que a maior parte do aquecimento global dos últimos 50 anos decorre da emissão de gases do efeito-estufa, em especial, o dióxido de carbono, por atividades humanas.

Ali se previu que a temperatura média da Terra poderá subir, neste século, de $1,8^{\circ} \mathrm{C}$ a $4^{\circ} \mathrm{C}$, com impactos catastróficos decorrentes de eventos extremos, como tempestades e furacões, ondas de calor, desertificação de extensas áreas, derretimento das calotas polares, elevação do nível do mar etc. Para se ter uma idéia em termos comparativos, nos últimos cem anos, a temperatura média do globo cresceu "apenas" $0,7^{\circ} \mathrm{C}$.

A causa do aquecimento global, com uma certeza estimada em $90 \%$ pelos cientistas, decorre, como já se falou, da emissão dos gases estufa, como o metano, o óxido nitroso, o óxido de nitrogênio, mas, principalmente, o grande vilão que é o dióxido de carbono $\left(\mathrm{CO}_{2}\right)$, responsável por $80 \%$ do total das emissões desses gases e proveniente da queima de combustíveis fósseis (petróleo, gás natural, carvão). Para se ter uma idéia do crescimento da liberação desses gases, a concentração de carbono na atmosfera saltou de 288 partes por milhão, no período pré-industrial, para $379 \mathrm{ppm}$ em 2005. A relação de causa e efeito entre a concentração de gás carbônico na atmosfera e o aquecimento do globo já foi demonstrada pela ciência. Portanto, para se impedir que o aumento da temperatura média da Terra ultrapasse o nível crítico de $2^{\circ} \mathrm{C}$ (que é considerado pelos cientistas como o ponto de não-retorno), se faz necessária 
uma drástica redução da liberação desses gases-estufa em torno de 50 a $60 \%$, aproximadamente, muito acima, pois, das metas do Protocolo de Kyoto.

Em se mantendo o atual nível de emissão de carbono, os impactos sobre o Brasil não são menos dramáticos do que no resto do mundo: perda de 60 a $70 \%$ da cobertura da floresta amazônica, que poderia se transformar em um imenso cerrado, com impactos gravíssimos sobre o regime de chuvas em todo o continente; a agudização do problema hídrico do nosso semi-árido nordestino, que poderia se transformar em deserto, atingindo em torno de 30 milhões de pessoas; erosão na zona costeira do país, com o acréscimo do nível do mar, afetando cerca de 40 milhões de brasileiros; chuvas e tempestades mais freqüentes na região Sudeste etc.

Essas previsões encontram-se não somente nos estudos do IPCC, mas também já vêm sendo objeto de análise por parte de cientistas brasileiros, em especial dos que se encontram no Instituto Nacional de Pesquisas Espaciais (INPE), que, inclusive, têm reclamado do governo brasileiro a adoção de uma política nacional de mudanças climáticas, que possa, a um só tempo, dar conta dos desafios da prevenção desses eventos, da proposição de políticas públicas voltadas para o combate ao desmatamento e queima das florestas (principal responsável - 75\% - pela liberação de carbono pelo país, que nos coloca na triste colocação de quarto maior emissor mundial) e ao desenvolvimento sustentável, bem ainda pela formulação de políticas de adaptação a esses eventos climáticos extremos.

Não bastasse a falta de uma política nacional de mudanças climáticas, o governo Lula ainda transita na contramão da História, ao desconsiderar todos esses impactos globais em sua política de desenvolvimento. No recém-lançado - e propagado - Plano de Aceleração de Crescimento (PAC), o governo federal prevê, em todo o país, a construção de 77 termoelétricas, o que conflita frontalmente com o esforço pela redução de emissão de gases-estufa; estimula a expansão da fronteira agrícola, através da pavimentação de rodovias federais na região amazônica — que pode ter um impacto extremamente deletério sobre a floresta - e incentiva atividades extremamente poluentes e degradadoras, como a siderurgia e a construção civil. Isso para não falar em toda a pressão que se exerce sobre o setor ambiental do governo no sentido de flexibilizar e apressar os licenciamentos, como se vê agora no caso das hidrelétricas do rio Madeira

É por essa razão que entendemos, dada a situação de extrema criticidade do clima no planeta, que não é possível mais se pensar em desenvolvimento sem que se leve em conta todos os estudos recentes acerca do aquecimento global. É preciso lembrar, como diz David King, conselheiro científico do governo britânico, que "passamos o ponto de poder evitar a mudança climática perigosa. O que falamos agora é evitar a mudança climática catastrófica”.

Assim, queremos propor que, para o licenciamento de obra ou atividade que utilize recursos ambientais e/ou capaz de causar degradação ambiental, seja obrigatória a realização, por parte do empreendedor, do balanço de emissões (assimilação e liberação) de gases do efeito-estufa, em especial do dióxido de carbono, para a 
atmosfera. Tal balanço deve ser considerado, tanto na fase de construção, como de funcionamento do empreendimento e ser parte indispensável do estudo prévio de impacto ambiental e dos demais estudos ambientais previstos na legislação.

Além disso, em nosso entendimento, devem ser considerados, em todos os estudos ambientais para fins de licenciamento, no diagnóstico ambiental da área do projeto e de sua área de influência, os estudos científicos produzidos sobre o tema, a fim de que possam ser cruzadas as previsões acerca dos impactos do aquecimento global sobre a área de influência do projeto com os impactos causados por este à atmosfera; garantindo-se, assim, tanto um rigor na análise da área do empreendimento vis-à-vis as mudanças climáticas, como um balanço adequado que possa reduzir ou neutralizar a emissão de gases-estufa. Devem, ainda, ser consideradas, como medidas mitigadoras aquelas que objetivem neutralizar ou compensar a liberação desses gases para a atmosfera.

Sabemos que tanto o licenciamento como a avaliação de impacto ambiental são poderosos instrumentos da política nacional do meio ambiente, e concretizam, em nossa legislação constitucional e infraconstitucional, o princípio da precaução, consagrado na Conferência de Cúpula do Meio Ambiente, realizada no Rio de Janeiro, em 1992. O que se trata, neste momento crítico, é garantir que, além de todos os impactos sócioambientais analisados no processo de licenciamento de obra ou atividade sobre sua área de influência, se faça o balanço de emissão de gases-estufa, para assegurar uma política rigorosa, responsável e ambientalmente sustentável de redução desses gases. Assim, o país adotaria o que o Greenpeace e a Rede Internacional de Ação pelo Clima denominam "Trilha da Descarbonização", segundo a qual o crescimento se daria a partir de "parâmetros de sustentabilidade e de redução de emissões" (Mudanças de Clima, Mudanças de Vida, Greenpeace, 2006, p. 14). A palavra está com o Governo, o Congresso Nacional e o Conselho Nacional do Meio Ambiente. A omissão será o nosso maior crime e nosso pior legado para as gerações atuais e futuras. 